\title{
RECURRENT APHTHOUS STOMATITIS RELATED TO PSYCHOLOGICAL STRESS, FOOD ALLERGY AND GERD
}

Rina Kartika Sari ${ }^{\star}$, Diah Savitri Ernawati ${ }^{* *}$, Bagus Soebadi**

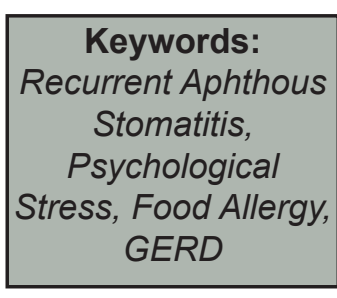

\section{ABSTRACT}

Background: Recurrent Aphthous Stomatitis (RAS) is inflammation in oral mucosa characterized by recurrent single or multiple ulcers that usually affected in non keratinized mucosa. Etiology RAS is unknown but psychological stress, allergy, and gastrointestinal disease can be predisposing factors

Case Management: A $23^{\text {rd }}$ years old complained recurrent oral ulcer with free ulcer period for 3-5 days. The patient had a history of food allergy, GERD and psychological stress. Intraoral examination showed recurrent multiple ulcers in variation site of the mouth. DASS 42 screening showed high stress and high anxiety. Skin Prick Test showed positive allergy to kapok, beef, chicken, cow milk, white egg, duck egg, shrimp, cob fish, milkfish, chocolate, and peanut. Ulcers treated with nonsteroid antiinflammation Aloe Vera gel and stress management by reading assignment method.

Discussion: Psychological stress altered the immune system so oral mucosa prone to inflammation, and make the history of GERD getting worse. Stress causes cortisol secretion that changes the imbalance of proinflammatory and antiinflammatory cytokines. Oral mucosa becomes more susceptible to hypersensitivity. In addition, stress decreased oral and esophageal mucosa resistance to GERD

Conclusion: RAS triggered by psychological stress, allergy, and GERD. Treatment of RAS is by elimination predisposing factors to prevent recurrence.

\section{PENDAHULUAN}

Stomatitis aftosa rekuren (SAR) adalah suatu peradangan yang terjadi pada mukosa mulut, berupa ulser putih kekuningan. Ulser ini dapat berupa ulser tunggal maupun lebih dari satu. SAR dapat menyerang mukosa mulut yang tidak berkeratin yaitu mukosa bukal, labial, lateral dan ventral lidah, dasar mulut, palatum lunak dan mukosa orofaring dengan karakteristik gambaran klinis berupa ulkus nekrotik dengan batas jelas dan dikelilingi erythematous halo ${ }^{1}$

RAS adalah penyakit pada rongga mulut dengan prevalensi sebesar 5-25\% dari populasi. RAS banyak terjadi pada usia 10-40 tahun dan banyak terjadi pada wanita serta individu dengan tingkat sosioekonomi yang tinggi ${ }^{2}$
Stomatitis aftosa rekuren (SAR) merupakan manifestasi yang timbul dalam rongga mulut yang dipicu oleh faktor predisposisi. Beberapa faktor predisposisi SAR yaitu kekurangan hematinik (zat besi, folat, dan vitamin B12), menstruasi, stres, alergi, dan AIDS ${ }^{3}$. RAS juga banyak terjadi pada orang-orang yang mempunyai stres berat kemungkinan dikarenakan saat stres terjadi penurunan sistem imun dan menyebabkan destruksi jaringan ${ }^{4}$. Beberapa makanan seperti coklat, kopi, kacang, sereal, almond, stroberi, keju, tomat dan tepung gandum (mengandung gluten) dapat menyebabkan RAS pada beberapa orang. Penelitian melaporkan adanya hubungan yang kuat antara tingginya kadar protein antibody IgA, IgG dan IgG anti susu sapi pada orang dengan recurrent aphthous ulcers ${ }^{5}$. Stres psikologis

\footnotetext{
*Oral Medicine Department, Faculty Of Dentistry, Universitas Islam Sultan Agung, Semarang, Indonesi, ** Oral medicine Department, Faculty of Dental Medicine, Universitas Airlangga, Surabaya, Indonesia

Korespondensi: rina.kartika@unissula.ac.id
} 
diketahui berperan penting dalam pathogenesis motilitas usus yang abnormal termasuk berperan dalam pathogenesis gastroesophageal reflux disease (GERD). Stres diasumsikan memperparah gejala yang berhubungan dengan gastroesophageal reflux ${ }^{6}$.

\section{LAPORAN KASUS}

Pasien wanita berusia 23 tahun yang berprofesi sebagai dosen datang ke poli gigi mengeluhkan sariawan yang tidak sembuh pada pipi kiri sejak 1 bulan yang lalu yang diawali dengan tergigit kemudian menjadi sariawan. Pasien memiliki riwayat sering sariawan sejak kecil, semakin sering pada waktu remaja (sebulan 2-3 kali) dan terutama kuliah S2 akhir hingga saat ini mulai bekerja sebagai dosen. Sariawan muncul berpindah-pindah tiap 3-5 hari, sembuh sendiri dalam waktu 5-7 hari. Tiap kali sariawan kambuh pasien mengobati dengan Kenalog/Albothyl namun tetap mengalami kekambuhan. Saat ini, pasien mengaku merasa stres dengan pekerjaan barunya sebagai dosen baru.

Riwayat kesehatan pasien pernah mengalami GERD tahun 2015, pernah didiagnosis Non Spesific Chronic Lymphadenitis karena benjolan di leher (sejak akhir 2015), mempunyai riwayat alergi udang, telur, debu dan riwayat
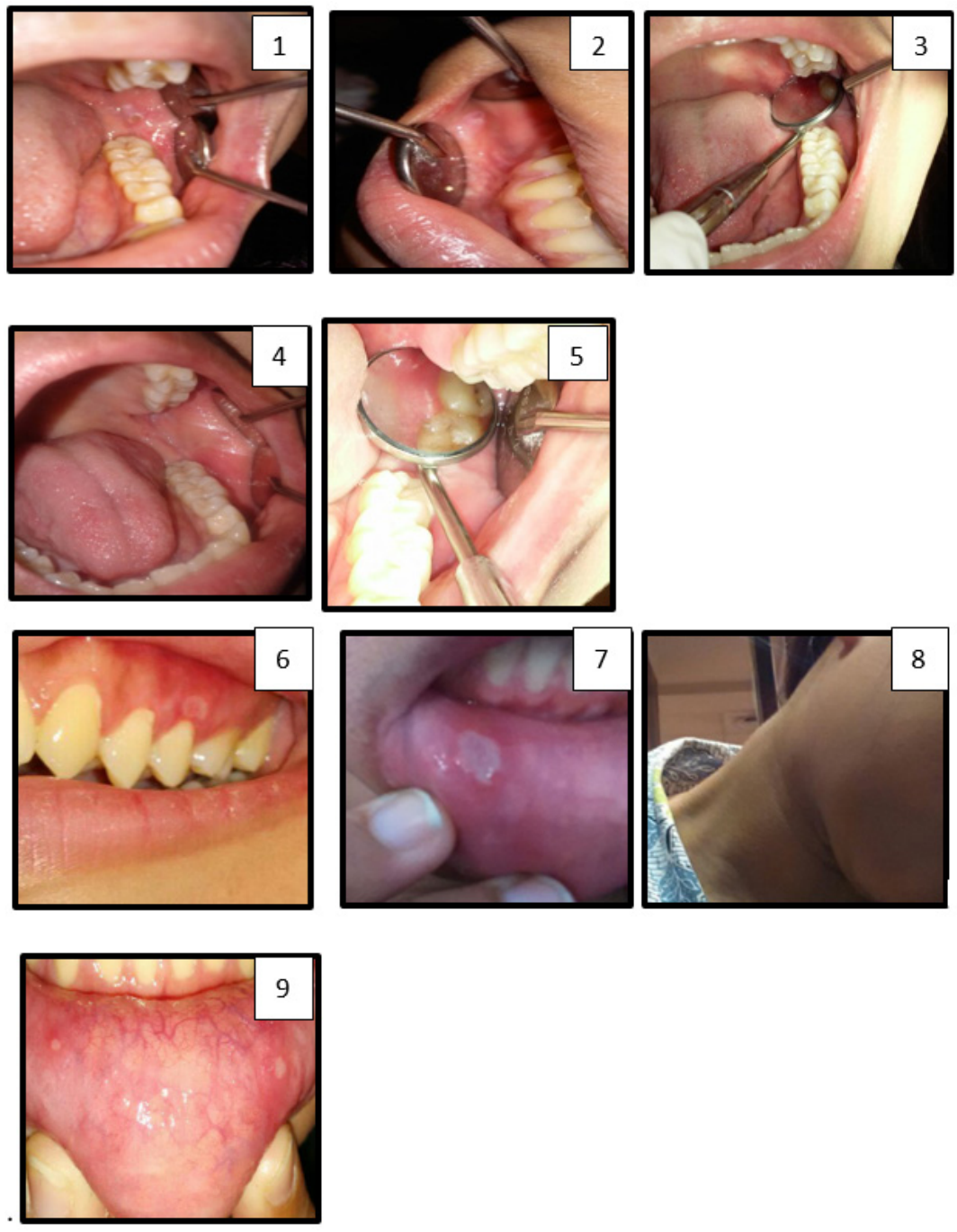

Gambar lesi RAS tiap kunjungan. (Gambar 1,2,3) Kunjungan I, (Gambar 4,5) Kunjungan II , (Gambar $6,7,8)$ Kunjungan III, (Gambar 9) Kunjungan IV. 


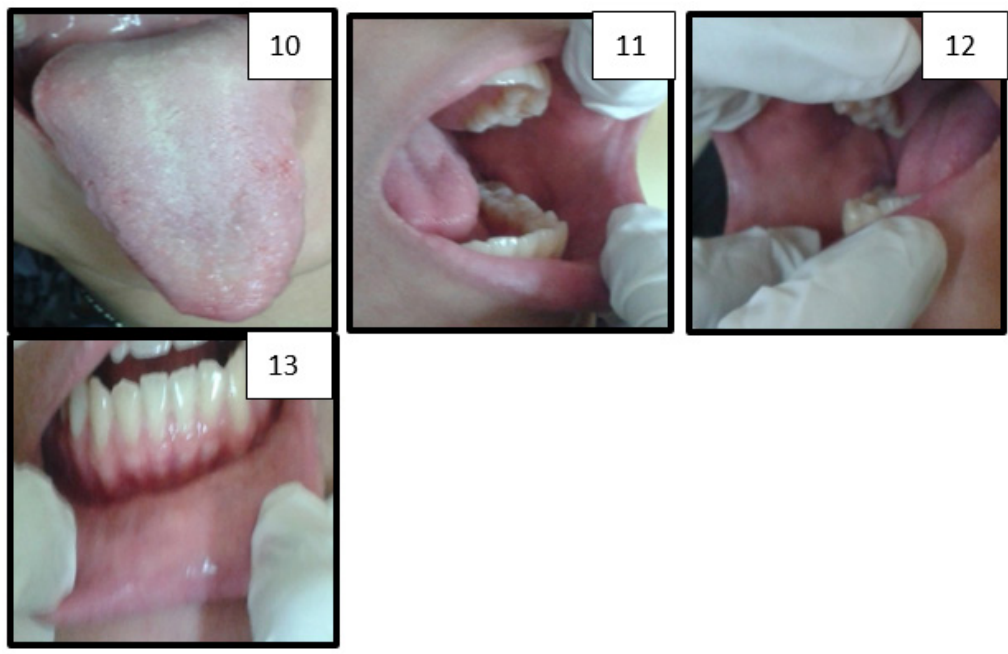

Gambar 10,11,12,13. RAS sembuh dan tidak ada kekambuhan setelah 2 bulan follow up

operasi usus buntu pada tahun 2014. Riwayat keluarga pasien, Ayah memiliki riwayat asma, alergi, hipertensi dan sariawan kambuhan. Ibu pasien memiliki riwayat diabetes, Adik perempuan riwayat tumor payudara dan adik laki-laki memiliki riwayat sariawan kambuhan. Riwayat sosial pasien mengaku seseorang yang selalu merasa cemas ketika mendapat tugas baru, orang yang selalu bersemangat pada pekerjaannya, pefeksionis dan sangat peduli pada kesehatannya. Pasien juga mengaku memiliki kebiasaan buruk bruxism.

Pemeriksaan ekstraoral terdapat pembesaran pada limfonodi post auricular-cervical sebelah kanan berukuran $\pm 5 \mathrm{~cm}$, kenyal, tidak sakit. Pemeriksaan intraoral menunjukkan ulkus single ukuran $2 \times 2 \mathrm{~mm}$ berwarna putih kekuningan, batas jelas, tepi kemerahan, sakit pada daerah retromolar kiri. Ulkus single ukuran $2 \times 2 \mathrm{~mm}$ berwarna putih kekuningan, batas jelas, tepi kemerahan, sakit pada mukosa labial bawah kanan. Ulkus single ukuran 2x1 mm berwarna putih kekuningan, batas jelas, tepi kemerahan, sakit pada gingival rahang atas kiri sebelah distal gigi molar terakhir. Diagnosis sementara Recurrent Apthous Stomatitis dipicu oleh stress psikologis, GERD dan alergi.

Perawatan diberikan Aloe Vera gel diole- skan 4 kali sehari dan pasien di edukasi untuk mengkonsumsi obat secara rutin, menjaga kebersihan mulut, menghindari makanan penyebab alergi (udang, telur) dan manajemen stres. Kunjungan berikutnya pasien mengalami sariawan kambuhan bersamaan dengan kekambuhan GERD yang dirasakan nyeri, panas pada tenggorokan hingga telinga. Pasien sudah menghindari makan udang namun sulit menghindari makan telur.dan selalu merasa khawatir dengan pekerjaan nya sebagai dosen karena pasien menginginkan segala sesuatunya berjalan baik dan sempurna.

Hasil pemeriksaan darah lengkap menunjukkan peningkatan jumlah eritrosit, RDW dan persentase eosinofil serta penurunan MCV dan $\mathrm{MCH}$. Hasil endoskopi yang lalu menunjukkan kerusakan mukosa esophagus klas $A$ dengan diagnosis GERD. Hasil pemeriksaan DASS 42 menunjukkan tingkat stress tinggi (skor 26), tingkat kecemasan tinggi (skor 17) dan tingkat depresi rendah/normal (skor 9). Hasil Pemeriksaan Skin Prick Test menunjukkan pasien alergi terhadap inhalan kapuk dan makanan (daging sapi, daging ayam, susu sapi, putih telor ayam,putih telor itik, kuning telor itik, udang,tongkol, bandeng, coklat dan kacang tanah 
Perawatan tetap melanjutkan pengobatan Aloe Vera gel dan edukasi untuk managemen stress, menghindari makanan penyebab alergi, makan makanan yang tinggi zat besi dan asam folat, menjaga kebersihan mulut dan cukup minum air putih dan menyarankan untuk pencabutan gigi 28 yang malposisi. Pasien mendapatkan saan dari dokter psikiatri untuk reading assignment tentang psychosomatic dan stomatitis, menyarankan untuk rekreasi, menjaga pola makan dan olahraga

Setelah 2 bulan, pasien tidak pernah lagi mengeluhkan sariawan. Pasien mengaku sudah lebih nyaman dengan pekerjaannya sebagai dosen, lebih baik dalam manajemen stress, sudahmelakukan tugas dari psikiatri dengan membaca jurnal dan artikel medis yang disarankan, sering memposting komentar mahasiswa yang positif tentang dirinya dan semakin bersemangat dalam bekerja. Pasien sudah menghindari makanan penyebab alergi. Pasien juga sudah tidak pernah mengeluhkan sakit tenggorokan.

Pemeriksaan DASS 42 terakhir menunjukkan tingkat stres ringan, kecemasan normal dan depresi normal. Benjolan pada leher masih ada namun ukuran tetap dan tidak ada pertambahan di bagian lain. RAS telah sembuh. Kekambuhan jauh berkurang. Berdasarkan hasil USG, benjolan pada leher bukan suatu manifestasi keganasan (Non Spesific Limphadenopathies)

\section{DISKUSI}

Recurrent aphthous stomatitis (RAS) atau Stomatitis aftosa rekuren (SAR) merupakan manifestasi yang timbul dalam rongga mulut yang dipicu oleh faktor predisposisi. Etiologi RAS belum diketahui dengan jelas namun ada beberapa faktor predisposisi SAR yaitu faktor genetic, kekurangan hematinik (zat besi, folat, dan vitamin B12), menstruasi, stres, alergi, alergi makanan,trauma local, merokok, produk kimia dan agen mikroba ${ }^{2,3}$. RAS ditandai dengan munculnya ulkus nekrotik di awal dengan tepi yang jelas dan dikelilingi area kemerahan. Lesi kebanyakan terjadi pada mukosa tidak berkeratin dan dapat sembuh sendiri.

Pada pasien ini, RAS yang terjadi dipicu oleh beberapa faktor antara lain stres psikologis, alergi makanan dan GERD yang terjadi bersamaan. Dimana stres pada pasien merubah sistem imun sehingga rentan terhadap peradangan pada rongga mulut, memudahkan terjadinya alergi pada pasien yang sudah memiliki riwayat alergi pada diri sendiri dan keluarga serta memperparah riwayat GERD yang sudah ada sebelumnya sehingga pembesaran kelenjar limfe pada leher juga semakin parah. Ketika pasien sudah mampu beradaptasi dengan stres, semua gejala diatas mereda dan frekuensi kekambuhan RAS berkurang dan hampir tidak ada.

Pada kondisi stres, Korteks adrenal akan mensekresi kortisol yang akan menyebabkan penurunan produksi IFN-y (sitokin tipe 1) dan meningkatkan produksi IL-10 dan IL-4 (sitokin tipe 2) yang akan memicu terjadinya perubahan keseimbangan sitokin tipe 1/tipe 2 yang lebih ke arah respon tipe 2. Namun, penelitian terbaru menyatakan bahwa disregulasi dari keseimbangan sitokin tipe 1/tipe 2 inilah yang memainkan peranan penting dalam menghubungkan pengaruh stres terhadap sistem imun. Terdapat beberapa respon imun yang terjadi pada RAS, yaitu penurunan jumlah limfosit CD4 dan perubahan rasio CD4:CD8, penurunan aktivitas regulasi Treg CD4 CD25, peningkatan jumlah limfosit $B$, peningkatan jumlah sel T, penurunan ekspresi HSP, peningkatan sistem komplemen, peningkatan 
jumlah NK sel, reaktivasi dan hiper reaktif dari neutrofil, penurunan ekspresi sitokin anti inflamasi yang dihasilkan oleh Th2 dan TGF $\beta$, peningkatan ekspresi sitokin pro inflamasi yang dihasilkan oleh Th1 dan IL-2, IL-12, IFN-gamma dan TNFa ${ }^{7}$.

Pada respon humoral, level dari IgA saliva pada pasien dengan RAS menunjukkan peningkatan pada periode akut dan berkurang dalam periode regresi dan penyembuhan. Selain IgA, terjadi peningkatan level IgG dan IgM. IgG dan komplemen bekerja saling membantu sebagai opsonin pada pemusnahan antigen. IgG memiliki sifat opsonin yang efektif karena sel - sel fagosit, monosit dan makrofag, mempunyai reseptor untuk fraksi Fc dari lgG sehingga dapat mempererat hubungan antara fagosit dan sel target. Berbagai perubahan tersebut dapat mengakibatkan keadaan patologis pada sel epitel mukosa rongga mulut, sehingga sel epitel lebih peka terhadap rangsangan ${ }^{7}$.

Pasien memiliki riwayat alergi makanan yaitu udang, telur dan debu. Setelah pemeriksaan skin prick test didapatkan hasil pasien alergi terhadap inhalan kapuk dan makanan (daging sapi, daging ayam, susu sapi, putih telor ayam,-putih telor itik, kuning telor itik, udang,tongkol, bandeng, coklat dan kacang tanah). Sebelumnya pasien hanya menyadari alergi terhadap udang dan telur (hasil positif 1 ) berupa gatal dan kadang bersin-bersin setelah makan. Namun pasien tidak mengetahui bahwa cokelat juga menyebabkan alergi (hasil positif 3) dan pasien sering mengkonsumsi cokelat selama ini. Setelah mengetahui hal tersebut, pasien menghindari makan cokelat. Pasien baru menyadari alergi terhadap makanan tersebut dan mengakui setelah makan makanan tersebut, muncul sariawan di rongga mulut. Selain itu riwayat keluarga pasien Ayah dan adik kandung laki-laki juga memiliki riwayat alergi, asma dan sariawan sehingga dapat disimpulkan RAS yang diderita pasien berhubungan dengan alergi makanan.

Reaksi alergi klasik yang dimediasi oleh lgE mempunyai gambaran spesifik yaitu bersifat segera/cepat, bisa berulang dengan paparan makanan yang samadan dapat dideteksi dengan adanya IgE spesifik terhadap makanan tersebut. Alergen yang terkandung dalam makanan menstimulasi system imun dengan membentuk antibody lgE spesifik terhadap komponen makann. IgE kemudian memasuki sirkulasi darah dan berikatan dengan basofilatau memasuki jaringan (misal kulit, mukosa, paru, saluran cerna) dimana kemudian berikatan dengan sel mast. Reaksi alergi diawali dengan ikatan antara allergen dengan antibody IgE yang telah terikat dengan reseptor berafinitas tinggi (FcERI) yang diekspresikan pada sel mast dan basofil, serta pada reseptor yang berafinitas rendah (FcERII) pada makrofag, monosit, limfosit dan trombosit. Ikatan silang antara alergen dengan reseptor pada sel mast dan basofil memicu degranulasi sehingga melepaskan mediator seperti histamine, prostaglandin, leukotrien dll yang menimbulkan berbagai macam manifestasi klinis termasuk RAS pada rongga mulut ${ }^{8}$.

Bersamaan dengan adanya faktor stress dan alergi, pasien juga mengeluhkan sakit tenggorokan yang terasa perih dan panas terbakar hingga nyeri sampai ke telinga. Hal ini dirasakan sudah sejak 2 tahun yang lalu kurang lebih bersamaan dengan munculnya benjolan pada leher. Pasien sudah diperiksa endoskopi dan menunjukkan kerusakan mukosa klas A pada esophagus dan didiagnosis sebagai GERD. Pasien sempat menerima terapi, sudah mereda namun sekarang kambuh lagi. Pasien sudah disarankan untuk kembali berobat namun pasien mengaku belum ada wak- 
tu untuk berobat. Setelah pasien menyadari kondisi stress nya berdampak pada banyak hal, dan mulai manajemen stress diri sendiri, keluhan GERD juga menghilang.

Beberapa hal yang berpengaruh terhadap pathogenesis GERD adalah infeksi H.Pylori, kebiasaan/gaya hidup, peranan motilitas, dan hipersensitivitas visceral. Esofagitis pada GERD terjadi akibat refluks dari lambung ke esophagus jika terjadi kontak yang lama antara bahan refluksat dengan mukosa esophagus, terjadi penurunan resistensi jaringan mukosa esophagus meski kontak dengan bahan refluksat tidak lama, dan terjadi gangguan sensitivitas terhadap rangsangan isi lambung yang disebabkan adanya persepsi neural esophageal baik sentral maupun perifer ${ }^{9}$.

Diagnosis ditegakkan berdasarkan anamnesis, gambaran klinis dan pemeriksaan penunjang. Anamnesis pasien mengaku sangat stres dan cemas dengan pekerjaan barunya sebagai dosen. Berdasarkan anamnesis dan pengamatan operator, pasien adalah seseorang yang perfeksionis karena berdasarkan cerita pasien selalu berusaha mengerjakan tugasnya sebaik-baiknya hingga sering menyita waktu dan pikirannya. Pasien lebih suka tugas yang diberikan dikerjakan sendiri dibanding jika harus kerja tim. Orang tua pasien seorang dosen juga, dan pasien ingin membuktikan bahwa dirinya mampu meski orang tuanya tidak terlalu menuntutnya. Untuk mengerjakan tugas sebaik-baiknya dan berprestasi di sekolahnya, pasien memilih menghabiskan waktu berjam - jam di perpustakaan. Pasien merasa stres jika dia mendapat tugas yang tidak sesuai dengan keahliannya/jika pasien merasa tidak menguasai. Pasien sering diminta menggantikan tugas mengajar oleh dosen-dosen yang lebih senior. Dari pengamatan operator pasien memiliki kepribadian yang berseman- gat, kadang khawatir berlebihan, terbuka, perhatian dengan kondisi tubuhnya. Pasien sangat peduli dengan kondisinya dan bersedia menjalani pemeriksaan apapun yang dibutuhkan. Sedangkan hasil pemeriksaan DASS 42 menunjukkan tingkat stress dan kecemasan yang tinggi namun tingkat depresi normal.

Hasil pemeriksaan darah lengkap menunjukkan hasil peningkatan jumlah eritrosit, RDW dan persentase eosinofil serta penurunan MCV dan $\mathrm{MCH}$. Eritrosit yang tinggi menunjukkan hemokosentrasi (Perburukan DHF, Resistensi Insulin), PPOK( Penyakit Paru Obstruktif Kronik), Jantung Kongestif, Perokok, Preeklamsi, penggunaan Obat-obat (Gentamicyn, methyldopa) dll, RDW yang tinggi menunjukkan Anemia Defisiensi Besi, Anemia Defisiensi Asam Folat, Anemia Defisiensi Vitamin B12. Kadar $\mathrm{MCV}$ dan $\mathrm{MCH}$ yang rendah menunjukkan Anemia defisiensi besi, thalasemia, keracunan timah. Dari hasil diatas dapat disimpulkan bahwa pasien mengalami kecenderungan anemia. Berdasarkan pengakuan pasien, karena kesibukannya pasien sering melewatkan waktu makan dan sering minum kopi dan teh. Sehingga asupan nutrisi pasien kurang. ${ }^{8,9}$

Berdasarkan konsultasi dengan bagian psikiatri, karena pasien tidak ada waktu untuk ke bagian psikiatri, pasien disarankan untuk Reading assignment tentang psychosomatic dan stomatitis, menyarankan untuk rekreasi, menjaga pola makan, diet, olahraga dengan pertimbangan mengingat pasien tipe orang yang berpendidikan, pintar, sangat peduli dan perfeksionis dalam segala hal sehingga pasien berkenan menjalankan hal tersebut. Pada akhir kunjungan skor DASS menjadi tingkat stres ringan, kecemasan normal dan depresi normal. ${ }^{9}$

Perawatan untuk lesi intraoral diberikan obat oles anti inflamasi non steroid untuk men- 
gurangi peradangan yaitu obat kumur yang mengandung aloe vera. Aloe vera memiliki beberapa senyawa anti inflamasi. Aloclair memiliki berbagai kandungan di dalamnya antara lain Aqua, maltodextrin, propylene glycol, polvinylptrrolidone (PVP), aloe vera ekstrak, Kalium sorbate, Natrium benzoate, hydroxyethylcellulose, PEG 40, hydrogenated castor oil, disodiumedetate, benzalkonium, Klorida, saccharin Natrium, Natrium hyaluronate, glycyrrhetic acid. Bahan yang dapat mempercepat penyembuhan sariawan diantaranya ialah Polyvinylpyrrolidone (PVP) yang dapat befungsi untuk antibakteri dan menurunkan infeksi serta giberelin yang diketahui dapat berinteraksi dengan reseptor faktor pertumbuhan pada sel fibroblas sehingga akan meningkatkan aktivitas dan proliferasi dari kontraksi luka pada proses penyembuhan luka ${ }^{10,11}$

Pasien juga diberikan multivitamin (Becom-Zet) dan vitamin B1, B6, B12 dari bagian psikiatri. multivitamin (Becom-Zet) yang mengandung Vit E $30 \mathrm{iu}$, vit C $750 \mathrm{mg}$, vit B1 15 $\mathrm{mg}$, vit B2 $15 \mathrm{mg}$, vit B6 $20 \mathrm{mg}$, vit B12 12 $\mathrm{mcg}$, folic acid $400 \mathrm{mcg}$, pantothenic acid 20 mg, Zn 22.5 mg, niacin 100 mg. Fungsi dari masing-masing multivitamin dan mineral ini adalah vitamin $\mathrm{E}$ dan $\mathrm{C}$ berfungsi sebagai antioksidan, dan perbaikan sistem imun, mempercepat penyembuhan luka, pembentukan jaringan ikat., vitamin B1 (Tiamin), vitamin B2 (riboflavin), niacin berfungsi metabolisme karbohidrat, vitamin B6 (piridoksin) berfungsi untuk metabolisme protein dan glikogen., vitamin B12 (cobalamin) dan asam folat berfungsi untuk pembentukan sel darah merah, dan sintesis DNA, asam pantotenat berfungsi untuk sistesis lemak, zinc berfungsi untuk regenerasi sel, metabolisme karbohidrat, membantu mempercepat regenerasi jaringan yang rusak, meningkatkan proses penyembuhan luka.

\section{KESIMPULAN}

RAS dapat dipicu oleh beberapa faktor salah satunya stress psikologis yang dapat merubah system imun dan jaringan tubuh termasuk meningkatkan resiko alergi dan menurunkan ketahanan mukosa. Eliminasi faktor pemicu merupakan terapi utama RAS untuk mencegah rekurensi dan mengurangi frekuensi

\section{DAFTAR PUSTAKA}

1. Kumar A M., Ananthakrishnan V, Goturu J. 2014. Etiology And Pathophysiology Of Recurrent Aphthous Stomatitis: A Review. Int J Cur Res Rev. 06 (10)

2. Belenguer-Guallar I, Jiménez-Soriano Y, Claramunt-Lozano A. 2014. Treatment of recurrent aphthous stomatitis: A literature review. J Clin Exp Dent. 2014;6(2):e168-74

3. Junhar GM, Suling PL, Supit ASR. 2015. Gambaran Stomatitis Aftosa Rekuren Dan Stres Pada Narapidana Di Lembaga Pemasyarakatan Kelas li B Bitung. Jurnal E-Gigi (Eg).3 (1)

4. Hernawati, S. 2014. Mekanisme Seluler dan Molekuler Stres Terhadap Terjadinya Recurrent Apthous Stomatitis. Jurnal PDGI. (63):1

5. Tarakji B, Gazal G, Al-Maweri SA, Azzeghaiby SN, Alaizari N. 2015. Guideline for the Diagnosis and Treatment of Recurrent Aphthous Stomatitis for Dental Practitioners. Journal of International Oral Health; 7(5):74-80

6. Song, EM, Jung HK, Jung JM. 2013. The Association Between Reflux Esophagitis and Psychososial Stress. Dig Dis Sci. 58:471-477

7. Slebioda Z, Zsponar E, Kowalska A. 2014. Etiopathogenesis of Recurrent Apthous Stomatitis and The Role of Immunologic Aspects : A Literature Review. Arch Immunol Ther Exp. 63:205215

8. Baskoro H.. 2015. Buku Ajar IImu Penyakit Dalam. Edisi 2. Surabaya:Airlangga University Press. Hal. 484-192

9. Nusi S.. 2015. Buku Ajar IImu Penyakit Dalam. Edisi 2. Surabaya:Airlangga University Press. Hal. 484-192

10. Furnawanthi, I., 2007, Khasiat dan Manfaat Lidah Buaya Si Tanaman Ajaib Ed.8, Jakarta Selatan: PT. AgroMedia Pustaka, Hal. 1-29.

11. Susanto H. 2015. Xerostomia severity difference between elderly using alcohol and non alcohol-containing mouthwash. Dental Journal (Majalah Kedokteran Gigi). 48(3): 109-112 